\title{
Ефективність застосування комплексної програми фізичної реабілітації дітей шкільного віку 3 коротко- зорістю на санаторному етапі
}

\author{
'Вікторія Онищук \\ 1Наталія Гаврилова \\ 1 Ірина Мацейко \\ олександр Звіряка
}

${ }^{1}$ Вінницький державний педагогічний університет імені

М. Коцюбинського, Вінниця, Україна

${ }^{2}$ Сумський державний педагогічний університет імені

А.С. Макаренка, Суми, Україна

Мета: обгрунтувати та розробити комплексну програму фрізичної реабілітації з використанням спеціальних вправ у школярів 10-11 років з короткозорістю на санаторному етапі.

Матеріал і методи: для вирішення поставлених завдань використовувалися такі методи дослідження: огляд літературних джерел; візометрія; рефрактометрія; педагогічне тестування; методи математичної статистики.

Результати: проведені нами дослідження засвідчили, що через 22 дні від початку занять у школярів, які займалися за санаторною програмою реабілітації, відбулося поліпшення показників гостроти зору і рефрактометрії але не достовірно. Тоді як, у школярів експериментальної групи застосування авторської програми, яка включала розроблений комплекс спеціальних вправ для зору, гімнастичні вправи, ранкову гігієнічну гімнастику, дозовану лікувальну ходьбу по місцевості за розвішеними орієнтирами, рухливі ігри і естафеети з м'ячем, сприяло покращенню функції зорового аналізатора та показників фрізичної підготовленості на санаторному етапі фрізичної реабілітації.

Висновки: аналіз показників гостроти зори і рефрактометрії у дітей шкільного віку з короткозорістю, які займалися за авторською програмою фізичної реабілітації, дозволяє констатувати покращення функції зорового аналізатора та деяких показників фрізичної підготовленості.

Ключові слова: школярі, міопія, зоровий аналізатор, фрізична реабілітація, санаторний етап.

\section{Вступ}

Протягом останнього десятиліття медична статистика констатує неухильне зростання захворювань зорового аналізатора серед осіб різного віку. Особливо тривожним $\epsilon$ розповсюдженість очних захворювань серед дитячого населення. В Україні за даними Всесвітньої організації охорони здоров'я (ВОО3) більше 13\% дітей мають порушення зорового аналізатора [8, с. 1; 3 ]. Слід також зазначити, що найбільш розповсюдженими та прогресивними захворюваннями зорового аналізатора, серед дітей та підлітків $є$ короткозорість (міопія). Відомо, що в Україні 420 тисяч дітей страждають на короткозорість. За офріційною статистикою МОЗ України в 2015 році міопія була виявлена в 17\% школярів початкових класів і в 40\% підлітків загальноосвітніх шкіл. Медико-соціальне значення проблеми зростає у зв'язку з тим, що короткозорість розвивається в дітей та осіб працездатного віку, тому боротьба з короткозорістю є актуальною проблемою [6, с.108]. Більшість дослідників, офтальмологів, які працюють над проблемою профрілактики та лікування короткозорості у дітей, вважають, що головною причиною виникнення да- ної хвороби є послаблення сполучної тканини під впливом недостатньо контрольованого зорового навантаження, що супроводжується підвищенням передньо-задньої осі ока і стоншенням рогівки $[2,11,13]$. Зменшення товщини рогівки супроводжується зниженням ії чутливості від 19\% до 57\% в залежності від ступеня захворювання й зменшенням ригідності зовнішньої оболонки ока [6, с.1]. Наслідками слабкості сполучної тканини $€$ не тільки зниження зорових функцій, але і дистрофрічні зміни на очному дні [6, с.1; 11, с. 803]. Крім того, порушення функцій зорового аналізатора, особливо у дітей, призводить до важких незворотних процесів, а саме формування неправильної постави, плоскостопості, що обмежує рухову активність; порушення діяльності серцево-судинної, дихальної, нервової систем; зниження фуннціональних резервних можливостей організму тощо [4, с. $1 ; 5 ; 10$, с. 45; 7]. Такі зміни в організмі у дітей з короткозорістю спонукають до пошуку новітніх методів лікування спрямованих на укріплення загального стану здоров'я дітей і корекцію м'язового балансу акомодаційної системи ока з метою профілактики розвитку короткозорості і ускладнень цієї хвороби. Фізична реабілітація таких дітей є складним і тривалим 


\section{СЛОБОЖАНСЬКИЙ НАУКОВО-СПОРТИВНИЙ ВІСНИК:}

\section{Матеріали XIX Міжнародної науково-практичної конференції «Фізична культура, спорт і здоров'я: стан, проблеми та}

процесом, що потребує системного використання різних іiї засобів [1, 3, 9, 12]. Одним із ефективних напрямків вирішення даної проблеми, на нашу думку, є комплексне застосування засобів фрізичної реабілітації насанаторному етапі. Адже перебування дітей на санаторному етапі дозволить застосувати більший спектр засобів реабілітації, який буде сприяти розвантаженню зорової системи, усуненню прояву послаблення сполучної тканини, покращенню фрізичного станушколярів.

Мета дослідження: обґрунтувати та розробити комплексну програму фрізичної реабілітації з використанням спеціальних вправ у школярів 10-11 років з короткозорістю на санаторномуетапі.

Для досягнення мети вирішували такі завдання

1.Вивчити й узагальнити стан питання з даної проблеми.

2. Скласти комплексну програму фрізичної реабілітації для дітей шкільного віку з короткозорістю.

3. Оцінити ефективність впливу занять за розробленою програмою на показники гостроти зору, рефрактометрії та фрізичної підготовленості школярів.

\section{Матеріал і методидослідження}

Для вирішення поставлених завдань використовували наступні методи: огляд літературних джерел; для визначення гостроти зору застосовували метод візометрії, де використовували спеціальну таблицю «Головіна-Сівцева»; для визначення функціонального стану зорового аналізатора застосовували рефрактометрію, яку здійснювали на апараті «Auto Refractometer Rodenstock RX-520+» (виробник Німеччина); для визначення фізичного стану школярів застосовували тести фрізичної підготовленості (човниковий біг $4^{\times} 9$ м; штрафний кидок баскетбольного м'яча в кільце з відстані 3 м; метання набивного м'яча в рухову ціль 3 відстані 4 м); статистичну обробку отриманих показників проводили за t-критерієм Стьюдента.

В обстеженні взяли участь хлопці та дівчата віком 1011 років, які за станом здоров'я перебували на санаторномуетапі реабілітаціїудитячому лікувальномуДПсанаторії «Сокілець» Немирівського районуВінницькоїобласті. Курс фрізичної реабілітації становив 22 дні. Загальна кількість пацієнтів даного реабілітаційного закладу становила 103 особи, які мали порушення зорового аналізатора. Перед початком курсу фізичної реабілітації усі діти пройшли медичне (офтальмологічне) обстеження, де нами було відібрано 68 осіб (із них 35 дівчат та 33 хлопці) віком 10-11 років з міопією слабкого (55,8\%) та середнього $(44,2 \%)$ ступенів. Після чого досліджуваних розподілили на дві групи: контрольну (КГ), що складалася із 18 дівчат та 17 хлопців, та основну (ОГ) - 17 дівчат та 16 хлопців. Перед початком застосування реабілітаційних програм батьки дітей з порушенням зору давали добровільну згоду на проведення досліджень.

Хлопці та дівчата контрольної групи займалися за програмою фрізичної реабілітації спеціалізованого офтальмологічного санаторію. До змісту санаторноїпрограми входила медикаментозна терапія; фрізіотерапія (медикаментозний електрофорез, апаратне лікування, програмно-комп'ютерне лікування, ванни) та лікувальна фізична культура

Підґрунтям для розробки авторської комплексної програми фрізичної реабілітації хлопців та дівчат основної групи, стали дані науково-методичної літератури та резуль- тати констатувального експерименту, а саме показники функціонального стану органа зору досліджуваних.

Хлопці та дівчата основної групи займалися за авторською програмою, яка розроблялась фахівцями з фізичної реабілітації. Дана програма розроблялась з урахуванням даних обстеження фізичного стану та функціонального стану органа зору.

Особливістю даної програми було те, що поряд з фрізіотерапією, лікувальною гімнастикою до програми долучили розроблений комплекс спеціальних вправ для окорухових м'язів, ранкову гігієнічну гімнастику на свіжому повітрі (де застосовували координаційні, ідеомоторні, дихальні вправи), ігри у воді (з м'ячем), рухливі і спортивні ігри на спортивному майданчику (волейбол, бадмінтон, настільний теніс), дозовану лікувальну ходьбу по місцевості за розвішаними спеціально-розробленими орієнтирами (маршрутна карта №2)

У вступному періоді реабілітації (тривалість 5 дні) призначався щадний руховий режим. Завданням даного періоду було покращення м'язового - зв'язкового апарату ока, адаптація організму до фізичних навантажень, поліпшення кровообігу втканинах.

Лікувальна гімнастика. Школярі застосовували комплекс гімнастичних вправ: дихальні вправи динамічного та статичного характеру, релаксаційні вправи. Тривалість заняття з лікувальної гімнастики становила 35 хв. Вступна частина - 7-8 хв, основна - 22-23 хв, заключна - 5 хв.

Фізіотерапія. 3 метою досягнення спазмолітичного ефекту на ціліарні м'язи і міорелаксуючого впливу на судини ока застосовували медикаментозний електрофорез $1 \%$ мезатону, рибофрлавіну мононуклеотиду, вітамину $\mathrm{B}_{6}$. Дану процедуру здійснювали двічі на тиждень у фізіотерапевтичному кабінеті.

Два рази на тиждень дівчата та хлопці основної групи здійснювали водолікувальні процедури, де приймали лікувальні ванни (евкаліптові, хвойні). Тривалість приймання ванн становила 15-20 хвилин. Температура води становила 37-39 $\mathrm{C}^{\circ}$

Лікувальна ходьба. Також у вступному періоді реабілітації школярі основної групи займалися дозованою лікувальною ходьбою по місцевості за розвішанимиорієнтирами (маршрутна карта №2). Лікувальну ходьбу застосовували двічі на тиждень. Систематичні вправи на витривалістьпозитивно впливають не тільки на функціональний стан зорових аналізаторів але стабілізують загальний та психологічний станшколярів.

Самомасаж. Для зменшення очної втоми та затримки розвитку короткозорості до програми фрізичної реабілітації ми долучили самомасаж акупунктур них точок навколо ока.

У основному періоді реабілітації (тривалість 15 днів) призначався щадно-тренувальний руховий режим. Завданням даного періоду було підвищення рівня фізичного стану, зміцнення м'язів зорового аналізатора, поліпшення кровопостачання тканин ока і м'язової системи ока.

Лікувальна гімнастика. До комплексу вправ долучили дихальні вправи, координаційні, коригувальні, вправи на розтягування та розслаблення м'язів. Тривалість занять лікувальною гімнастикою становила 30 хв.

Ранкова гігієнічна гімнастика. Зранку хлопці та дівчата застосовували ранкову гігієнічну гімнастику, яка тривала 15 хв. До комплексу входили дихальні, коригувальні вправи.

Спеціальні вправи для окорухових м'язів. Хлопці і ді- 


\section{СЛОБОЖАНСЬКИЙ НАУКОВО-СПОРТИВНИЙ ВІСНИК:}

\section{Матеріали XIX Міжнародної науково-практичної конференції «Фізична культура, спорт і здоров'я: стан, проблеми та перспективи»}

вчата основної групи застосовували розроблений комплексспеціальнихвправ (рухи очнимияблуками вертикально: вгору-вниз; горизонтальні рухи очей: вправо-вліво; кругові рухи очима: за годинниковою стрілкою та в протилежному напрямку; зведення очей до носа; інтенсивне стискання та розтискання очей в швидкому темпі; часте кліпання очима на протязі 1-2 хвилин; розглядання міток на склі). Також до спеціальних вправ ми долучили заняття за корекційною методикою по В.В. Коваленко (1999). Суть методики полягала у застосуванні спеціальної офтальмологічної лінійки з позитивними і негативними сферичними лінзами зростаючої сили $( \pm 0,25 ; \pm 0,5)$ дптр. Заняття спеціальними вправами для очей проводили кожного дня. Тривалість занять становила 20 хв.

Рухливі іспортивні ігри. Для підсилення тонусу ціліарного м'яза та м'язів очного яблука до основного періоду реабілітації ми долучили спортивні (волейбол, настільний теніс, бадмінтон) та рухливі ігри (у воді, на спортивному майданчику). Заняття проводили тричі на тиждень по 30 Xв.

Фізіотерапія. Також школярі з короткозорістю відвідували фізіотерапевтичний кабінет, де застосовували апаратний комплекс «Струмочок ТАК - 6.2», «АСО-2» (виробникУкраїна). Апаратний комплекс «АСО-2» застосовувався двічі на тиждень, апаратний комплекс «Струмочок ТАК - 6.2» один раз на тиждень. По завершенню занять комп'ютерними програмами проводили лікувальний масаж для очей.

Також школярі у даному періоді продовжували займатися лікувальною ходьбою по місцевості.

У заключному періоді реабілітації (тривалість 2 дні) призначався тренувальний руховий режим. Завданнями даного періоду було підтримка рівня фрізичного стану, подальше зміцнення м'язів зорового аналізатора, формування у дітей мотивації до самостійних занять. Школярі основної групи продовжували застосовувати вищезгадані засоби фрізичної реабілітації.

Для оцінки змін у зоровому аналізаторі на початкута по завершенню курсу фрізичної реабілітації проводилося офртальмологічне обстеження контрольної та основної груп.

\section{Результати дослідження}

Для визначення ефективності розробленої реабілітаційної програми був проведений порівняльний аналіз показників гостроти зору та рефррактометрії хлопців, дівчат основної та контрольної груп. Результати проведеного констатуючого експерименту засвідчили, що показники гостроти зору у хлопців і дівчат обох груп суттєво не відрізнялися. Однак, через 22 дні від початку занять за програмою санаторію у хлопців контрольної групи достовірно покращилась середня гострота зору лівого ока на $28,5 \%$, а лівого на $21 \%(p<0,05)$. У хлопців основної групи, які займалися за розробленою програмою фізичної реабілітації також відбулося покращення гостроти зору. Середня величина показника гостроти зору правого ока зросла на $46 \%(p<0,05)$, тоді як лівого на $39 \%(p<0,05)$. Заняття за санаторною програмою фізичної реабілітації, не вплинуло протягом усього експерименту на суттєве покращення середніх величин показників зору у дівчат контрольної групи. Разом з тим проведений офтальмологічний огляд засвідчив незначне зростання середніх величин показників зору: правого ока з 0,52 до 0,68 ум.од., лівого ока 3 0,44 до 0,60 ум.од. По завершенню двадцяти двох денного курсу фрізичної реабілітації у дівчат основної групи середня величина показників гостроти зору, достовірно покращилися, як правого (на 42,8\%), так і лівого (на 45\%) ока , про що свідчать дані таблиці 1.

3 метою виявлення ступеню короткозорості ушколярів контрольних і основних груп досліджувався функціональний стан органа зору за рефрактометрією до початку експериментального дослідження і по завершенню. Як видно з таблиці 2 у хлопців контрольної групи протягом усього періоду застосування програми санаторію, показники рефррактометрії достовірно не змінились. Однак, середня величина показника рефрактометрії правого ока зросла на $12,5 \%$, а лівого - $18,8 \%$.

У хлопців контрольної групи вірогідно покращилися середні величини показників ресрактометрії, як правого $(46,6 \%, p<0,05)$, так і лівого $(37,5 \%, p<0,05)$ ока. У дівчат контрольної групи, середні величини показників рефрак-

Таблиця 1

Показники гостроти зору у хлопців і дівчат 10-11 років контрольної та основної груп

\begin{tabular}{|c|c|c|c|c|}
\hline \multirow{3}{*}{$\begin{array}{l}\text { Показники } \\
\text { гостроти зору }\end{array}$} & \multicolumn{4}{|c|}{ Середня величина, $\mathrm{X} \pm \mathrm{m}$} \\
\hline & \multicolumn{2}{|c|}{ контрольна група } & \multicolumn{2}{|c|}{ основна група } \\
\hline & $\begin{array}{l}\text { до фрізичної } \\
\text { реабілітації }\end{array}$ & $\begin{array}{c}\text { по } \\
\text { завершенню } \\
\text { фізичної реабілітації }\end{array}$ & $\begin{array}{l}\text { до фрізичної } \\
\text { реабілітації }\end{array}$ & $\begin{array}{c}\text { по завершенню } \\
\text { фізичної } \\
\text { реабілітації }\end{array}$ \\
\hline & \multicolumn{4}{|c|}{ хлопці } \\
\hline Гострота зору правого ока (VOD), ум.од & $0,50 \pm 0,1$ & $0,64 \pm 0,05^{*}$ & $0,41 \pm 0,07$ & $0,76 \pm 0,08^{*}$ \\
\hline \multirow[t]{2}{*}{ Гострота зору лівого ока (VOS), ум.од } & $0,50 \pm 0,06$ & $0,70 \pm 0,06^{*}$ & $0,40 \pm 0,09$ & $0,66 \pm 0,08^{*}$ \\
\hline & \multicolumn{4}{|c|}{ дівчата } \\
\hline $\begin{array}{c}\text { Гострота зору правого ока ь(VOD), } \\
\text { ум.од. }\end{array}$ & $0,52 \pm 0,07$ & $0,68 \pm 0,07$ & $0,40 \pm 0,1$ & $0,70 \pm 0,11^{*}$ \\
\hline Гострота зору лівого ока (VOS),ум.од & $0,44 \pm 0,08$ & $0,60 \pm 0,08$ & $0,38 \pm 0,03$ & $0,70 \pm 0,11^{*}$ \\
\hline
\end{tabular}

Примітка: вірогідної відмінності значення показника відносно величини, зареєстрованої до початку занять: ${ }^{*}-p<0,05$; 
СЛОБОЖАНСЬКИЙ НАУКОВО-СПОРТИВНИЙ ВІСНИК:

\section{Матеріали XIX Міжнародної науково-практичної конференції «Фізична культура, спорт і здоров'я: стан, проблеми та}

Таблиця 2

Показники рефрактометрії у хлопців і дівчат 10-11 років контрольної та основної груп

\begin{tabular}{|c|c|c|c|c|}
\hline \multirow{3}{*}{$\begin{array}{c}\text { Показники } \\
\text { рефррактометрії }\end{array}$} & \multicolumn{4}{|c|}{ 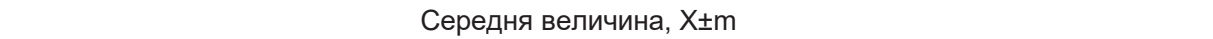 } \\
\hline & \multicolumn{2}{|c|}{ контрольна група } & \multicolumn{2}{|c|}{ основна група } \\
\hline & $\begin{array}{l}\text { до фрізичної } \\
\text { реабілітації }\end{array}$ & $\begin{array}{c}\text { по завершенню } \\
\text { фрізичної реабілітації }\end{array}$ & $\begin{array}{l}\text { до фрізичної } \\
\text { реабілітації }\end{array}$ & $\begin{array}{c}\text { по завершенню } \\
\text { фізичної реабілітації }\end{array}$ \\
\hline & \multicolumn{4}{|c|}{ хлопці } \\
\hline $\begin{array}{l}\text { Праве око } \\
\text { (VOD), дптр }\end{array}$ & $-1,6 \pm 0,4$ & $-1,4 \pm 0,2$ & $-1,5 \pm 0,3$ & $-0,8 \pm 0,2^{*}$ \\
\hline \multirow[t]{2}{*}{$\begin{array}{c}\text { Ліве око } \\
\text { (VOS), дптр }\end{array}$} & $-1,6 \pm 0,4$ & $-1,3 \pm 0,3$ & $-1,6 \pm 0,3$ & $-1,0 \pm 0,2^{*}$ \\
\hline & \multicolumn{4}{|c|}{ дівчата } \\
\hline $\begin{array}{l}\text { Праве око } \\
\text { (VOD), дптр }\end{array}$ & $-1,7 \pm 0,6$ & $-1,0 \pm 0,6$ & $-1,8 \pm 0,5$ & $-0,5 \pm 0,4^{*}$ \\
\hline $\begin{array}{l}\text { Ліве око } \\
\text { (VOS), дптр }\end{array}$ & $-1,8 \pm 0,6$ & $-1,0 \pm 0,4$ & $-1,9 \pm 0,3$ & $-0,9 \pm 0,4^{*}$ \\
\hline
\end{tabular}

Примітка: вірогідної відмінності значення показника відносно величини, зареєстрованої до початку занять: * $-p<0,05$

тометрії, протягом усього експерименту дещо знизились. Однак, достовірних відмінностей нами не було зафіксоваHo.

У дівчат основної групи показники рефрактометрії, порівняно зі значеннями, зареєстрованими до початку формувального експерименту, вірогідно знизились (праве око на $72 \%$, ліве око на $52 \%$ ), що свідчить про покращення функції зору. Отримані середні величинипоказників рефрактометрії, як у хлопців, так і у дівчат обох груп, до початку і по завершенню експерименту, свідчили про слабку та середню ступінь короткозорості.

Відомо, що повне або часткове порушення функції зорового аналізатора насамперед порушує просторове орієнтування, координацію рухів, швидкісну та силову витривалість, уповільнює темп оволодіння руховимивміннями й навичками, викликає труднощі в збереженні статичної та динамічної рівноваги. 3 цією метою ми долучили спеціальні тести фізичної підготовленості для школярів з короткозорістю.

Відомо, що під час виконання даних тестів покращується функціональний стан зорового аналізатора, підвищуються показники швидкості переробки зорової інформації, стійкості акомодації і швидкості розпізнавання.

Як видно з таблиці 3 середня величина показників спритності у хлопців контрольної та основної груп достовірно не змінилась. У дівчат контрольної групи також достовірних змін не виявлено, тоді як у школярок основної групи час пробігання дистанції зменшився на 9,4\% $(p<0,05)$.

Також ми запровадили спеціальний тест «штрафний кидок баскетбольного м'яча в кільце з відстані трьох метрів». У хлопців і дівчат контрольної групи показники покращилися але без суттєвих змін. У представників основної групи по завершенню курсу фізичної реабілітації

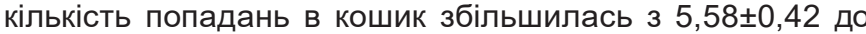
$8,03 \pm 0,54$ разів $(p<0,05)$. У дівчаток також зафріксовано достовірне збільшення кількості попадань м'ячем у кошик

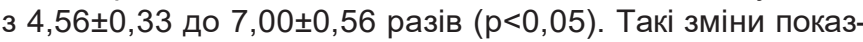
ників свідчать про покращення зорової орієнтації та периферичного зору.

Серед спектру спеціальних тестів для дітей з порушенням фрункції зору, виконання якого сприяє тренуванню зорового аналізатора, $є$ тест «метання в рухову ціль».
Через 22 тижні занять за санаторною програмою фізичної реабілітації у хлопців контрольної групи вірогідно збільшилась кількість попадань м'ячем в рухову ціль на 16,1\% $(p<0,05)$. У школярів основної групи, які займалися за розробленою програмою, даний показник покращився на $16,3 \%$ (р<0,05). У дівчаток контрольної групи кількість попадань в рухову ціль збільшилась але без суттєвих змін. Тоді як, у представниць основної групи даний показник покращився на 16,4\% ( $p<0,05)$, що свідчить про покращення функції зоровогоаналізатора

Отже, під впливом фрізичних навантажень у школярів основної групи показники фрізичної підготовленості за спеціально підібраними тестами значно змінились, що свідчить про ефективність використаних засобів фрізичної реабілітації на санаторномуетапі.

\section{Висновки /Дискусія}

Дискусія. Згідно отриманих даних можна стверджувати, що кількість дітей шкільного віку у яких простежується міопія значно збільшується. Згідно наукових даних Бутова P.C. (2016), Тимчик О. (2019) найчастіше погіршення зору простежується у шкільному віці, що і було підтверджено нашими даними.

Головною патогенетичною ланкою набутої короткозорості є розтягнення склери. Крім того, внаслідок порушення зоруу дітей виникають вторинні відхилення у фізичному здоров'ї, що негативно відображається на фрізичній активності. Наявна залежність між фізичною активністю, рівнем здоров'я дитини, і розвитком короткозорості свідчить про необхідність проведення комплексної фрізичної реабілітації (Ю.М. Фурман, 2014, А.І. Альошина, 2014). 3 огляду на вище викладене ми розробили і апробували комплексну реабілітаційну програму. Особливістю даної програми було те, що до програми ми долучили комплекс спеціальних вправ для зору, ігри у воді (з м'ячем), рухливі і спортивні ігри на майданчику (волейбол, бадмінтон, настільний теніс) та дозовану лікувальну ходьбу по місцевості за розвішаними спеціально-розробленими орієнтирами. Даний комплекс засобів фрізичної реабілітації підбирався з метою зміцнення м'язово - зв'язкового апарату ока, поліпшення діяльності м'язів ока, насамперед акомодаційного м'яза, зміцненнясклери. 


\section{СЛОБОЖАНСЬКИЙ НАУКОВО-СПОРТИВНИЙ ВІСНИК:}

\section{Матеріали XIX Міжнародної науково-практичної конференції «Фізична культура, спорт і здоров'я: стан, проблеми та перспективи»}

Таблиця 3

Показники фізичної підготовленості хлопців і дівчат 10-11 років контрольної та основної груп

\begin{tabular}{|c|c|c|c|c|}
\hline \multirow{3}{*}{$\begin{array}{l}\text { Тести фрізичної } \\
\text { підготовленості }\end{array}$} & \multicolumn{4}{|c|}{ Середня величина, $\mathrm{X} \pm \mathrm{m}$} \\
\hline & \multicolumn{2}{|c|}{ контрольна група } & \multicolumn{2}{|c|}{ основна група } \\
\hline & $\begin{array}{l}\text { до фрізичної } \\
\text { реабілітації }\end{array}$ & $\begin{array}{c}\text { по завершенню } \\
\text { фрізичної реабілітації }\end{array}$ & $\begin{array}{l}\text { до фрізичної } \\
\text { реабілітації }\end{array}$ & $\begin{array}{c}\text { по завершенню } \\
\text { фрізичної реабілітації }\end{array}$ \\
\hline \multirow{4}{*}{$\begin{array}{c}\text { Човниковий біг } \\
4 \times 9 \text { м, с }\end{array}$} & \multicolumn{4}{|c|}{ хлопці } \\
\hline & $11,3 \pm 0,15$ & $11,1 \pm 0,11$ & $10,6 \pm 0,22$ & $10,3 \pm 0,16$ \\
\hline & \multicolumn{4}{|c|}{ дівчата } \\
\hline & $12,6 \pm 0,36$ & $12,4 \pm 0,32$ & $12,7 \pm 0,11$ & $11,5 \pm 0,08^{*}$ \\
\hline \multirow{4}{*}{$\begin{array}{c}\text { Штрафний кидок } \\
\text { баскетбольного мяча в кільце } \\
\text { з відстані } \\
3 \text { м, кількість попадань }\end{array}$} & \multicolumn{4}{|c|}{ хлопці } \\
\hline & $6,18 \pm 0,7$ & $7,28 \pm 0,84$ & $5,58 \pm 0,42$ & $8,03 \pm 0,54^{*}$ \\
\hline & \multicolumn{4}{|c|}{ дівчата } \\
\hline & $4,46 \pm 0,45$ & $5,16 \pm 1,00$ & $4,56 \pm 0,33$ & $7,00 \pm 0,56^{*}$ \\
\hline \multirow{4}{*}{$\begin{array}{c}\text { Метання в рухову ціль } \\
\text { з відстані } 4 \text { м, кількість } \\
\text { попадань }\end{array}$} & \multicolumn{4}{|c|}{ хлопці } \\
\hline & $6,25 \pm 0,34$ & $7,45 \pm 0,33^{*}$ & $6,05 \pm 0,4$ & $7,23 \pm 0,32^{*}$ \\
\hline & \multicolumn{4}{|c|}{ дівчата } \\
\hline & $5,89 \pm 0,51$ & $6,22 \pm 0,42$ & $5,47 \pm 0,50$ & $6,54 \pm 0,20^{*}$ \\
\hline
\end{tabular}

Примітка: вірогідної відмінності значення показника відносно величини, зареєстрованої до початку занять: ${ }^{*}-p<0,05$

Застосування занять за авторською програмою сприяло достовірному покращенню середніх величин показників гостроти зору, рефрактометрії та фрізичної підготовленості у осіб основних груп. Такі зміни ми пов'язуємо з тим, що до комплексу заходів фрізичної реабілітації, які входили до авторської програми ми долучили спеціальні вправи для окорухових м'язів, що підвищило не тільки показники гостроти зору але й активну участь школярів у проведенні реабілітаційних заходів на санаторному етапі.

Отримані нами результати роботи про покращення фізичних якостей, гостроти зору та рефррактометрії у осіб 10-11 років з короткозорістю, з погляду на виконання наукового дослідження, відповідали попередньо поставленій меті, завданням фрізичної реабілітації та підтвердили есективність розробленої авторської програми, яка може бути. рекомендована до застосування у практичній діяльності пікувально-профрілактичних установ, реабілітаційних центрів відповідного профрілю

Висновки.

1. Узагальнення науково-методичної інформації зтеми дослідження свідчить про щорічну динаміку розповсюдженості короткозорості серед дітей шкільного віку.

2. Результати дослідження показали, що застосування комплексної програми фрізичної реабілітації дітей молодшого шкільного віку з короткозорістю, яка включає лікувальну гімнастику, ранкову гігієнічну гімнастику, спеціальні вправи для окорухових м'язів, дозовану лікувальну ходьбу по місцевості, рухливі ігри і естафети, сприяе покращенню показників гостроти зору, рефрактометрії та фрізичної підготовленості.

Перспективи подальших досліджень, на нашу думку, полягають у вивченні можливості застосування запропонованої програми фрізичної реабілітації для відновлення гостроти зору у школярів старшого віку на всіх етапах реабілітації.

Конфлікт інтересів. Автори заявляють, що немає конфлікту інтересів, який може сприйматися таким, що може нанести шкоду неупередженості статті. Джерела фінансування. Ця стаття не отримала фрінансової підтримки від державної, громадської або комерційної організації.

\section{Список посилань}

1. Аветисов, Э. С. (2005), Зрительные функции и их коррекция у детей, Москва, Медицина, 278 с.

2. Аветисов, Э. С. (1986), Близорукость, Москва, Медицина, 233 с.

3. Ананьєва, Т. Г., Тухар, В. О. (2016), "Застосування фрізіотерапевтичних методів у лікуванні міопії у дітей", Фізична реабілітація та рекреаційно- оздоровчі технології, № 3, С. 23-26.

4. Бутов, Р.С. (2016), Фізична реабілітація дітей шкільного віку з вадами зору в умовах спеціалізованих навчальних закладів: автореф. дис. канд. наук з фіз. вих. і спорту, Київ, 23 с.

5. Дугіна, Л. (2016), "Вплив засобів фрізичної реабілітації на фрізичний розвиток дітей з вадами зору", Фізична реабілітація та рекреаційно- оздоровчі технології, № 3, С. 67-72

6. Тимчик, О. (2019), "Фізична реабілітація дітей шкільного віку з міопією І-ІІІ ступеню", Спортивна наука та здоров'я людини, № 1 (2), C. $107-119$

7. Івасик, Н, Курташ, Є. (2010), "Лікувальне плавання, як засіб фрізичної реабілітації дітей молодшого шкільного віку з вадами зору", Теорія та методика фрізичного виховання, № 3, С. 27-29.

8. Ромман Хайсам Дж.М. (2015), Фізична реабілітація школярів з функціональними порушеннями зору на постклінічному етапі автореф. дис. канд. наук з фіз. вих. і спорту. Київ, 20 с.

9. Рубан, Л. А. (2016), "Методи корекції міопії фрізичними вправами", Педагогічні науки. Фізичне виховання та спорт, № 2, С. 193197.

10. Тейлор, Д., Хойт, К. (2007), Детская офтальмология, Москва, 248 с. 


\section{Матеріали XIX Міжнародної науково-практичної конференції «Фізична культура, спорт і здоров'я: стан, проблеми та}

11. Aslan, U. B., Calik, B. B., Kitiş, A. (2012), "The effect of gender and level of vision on the physical activity level of children and adolescents with visual impairment", Res Dev Disabil. J., № 33(6), C.799-804.

12. Cochereau, A. (2011), "Screening for visual disorders in pre-primary school" Soins. Pediatr. Pueric., № 261, pp. 24-25.

13. Walline, J.J., Lindsley, K., Vedilla, S.S. (2012), Myopia. Treatments for Kids Come Up Short or Cause Side Effects, Review of Ortometry, № 149 (1): 316 .

Стаття надійшла до редакції: 11.11.2019 р.

Опубліковано: 30.12.2019 р.

Аннотация. Онищук Виктория Евгеньевна, Гаврилова Наталья Владимировна, Мацейко Ирина Ивановна, Звиряка Александр Николаевич. Эффективность применения комплексной программы физической реабилитации детей школьного возраста 10-11 лет с близорукостью на санаторном этапе. В течение последнего десятилетия медицинская статистика констатируетнеуклонный рост заболеваний зительного анализатора улицразличноговозраста. Особеннотревожным является распространенность глазных заболеваний среди детского населения. В Украине по данным Всемирной организации здравоохранения (ВОЗ), более 13\% детей имеют нарушения зрительного анализатора. Следует также отметить, что наиболее распространеннымии прогрессивными заболеваниями зрительного анализатора, среди детей и подростков является близорукость (миопия). Офтальмологи, которые работают над проблемой профилактики и лечения близорукости у детей, считают, что главной причиной возникновения данной болезни является ослабление соединительной ткани под влиянием недостаточно контролируемой зрительной нагрузки, что сопровождается повышением передне - задней оси глаза и истончением роговицы. Последствиями слабости соединительной ткани является не только снижение зрительных функций, но и дистрофические изменения на глазном дне. Одним из эфффективных направлений решения данной проблемы, по нашему мнению, является комплексное применение средств фризической реабилитации на санаторном этапе. Ведь пребывание детей на санаторном этапе позволит применить больший спектр средств реабилитации, который будет способствовать разгрузке зрительной системы, устранению проявления ослабления соединительной ткани, улучшению физического состояния школьников. Цель работы обосновать и разработать комплексную программу физической реабилитации с использованием специальных упражнений у школьников 10-11 лет с близорукостью на санаторном этапе. Методы исследования. Для решения поставленных задач использовались следующие методы исследования: обзор литературных источников; визометрия; рефрактометрия; педагогическое тестирование; методы математической статистики. Результаты. Проведенные нами исследования показали, что через 22 дня от начала занятий у школьников, которые занимались по санаторной программе реабилитации, произошло улучшение показателей остроты зрения и рефрактометрии но не достоверно. Тогда как, ушкольников экспериментальной группы применения авторской программы, которая включала разработанный комплекс специальных упражнений для зрения, гимнастические упражнения, утреннюю гигиеническую гимнастику, дозированную лечебную ходьбу по местности с развешанными ориентирами, подвижные игры и эстафреты с мячом, способствовало улучшению функции зрительного анализатора и показателей фризической подготовленностинасанаторномэтапе физическойреабилитации. Выводы. Анализ показателейостротызрения ирефрактометрии у детей школьного возраста с близорукостью, которые занимались по авторской программе физической реабилитации, позволяет констатировать улучшение функции зрительного анализатора и некоторых показателей физической подготовленности.

Ключевые слова: школьники, миопия, зрительный анализатор, фризическая реабилитация, санаторный этап

Abstract. Onishchuk Victoria, Gavrilova Natalya, Matseyko Irina, Zviryaka Alexander. The effectiveness of the use of a comprehensive program of physical rehabilitation for school children 10-11 years old with myopia at the sanatorium stage. Over the past decade, medical statistics have shown a steady increase in the diseases of the visual analyzer in people of different ages. Particularly alarming is the prevalence of eye diseases among children. In Ukraine, according to the World Health Organization (WHO), more than $13 \%$ of children have visual analyzer disorders. It should also be noted that the most common and progressive disease of the visual analyzer among children and adolescents are myopia (myopia). Ophthalmologists who work on the prevention and treatment of myopia in children believe that the main cause of this disease is a weakening of connective tissue under the influence of insufficiently controlled visual load, which is accompanied by an increase in the anterior-posterioraxis of the eye and thinning of the cornea. The consequences of connective tissue weakness are notonly a decrease in visual functions, butalso dystrophic changes in the fundus. One ofthe effective ways to solve this problem, in our opinion, is the integrated use of physical rehabilitation at the sanatorium stage. After all, the stay of children at the sanatorium stage will make it possible to use a wider range of rehabilitation means, which will contribute to unloading the visual system, eliminating the manifestation of weakening of connective tissue, and improving the physical condition of schoolchildren. Purposes: to substantiate and develop a comprehensive program of physical rehabilitation using special exercises in schoolchildren 10-11 years old with myopia at the sanatorium stage. Methods of research. To solve the tasks, the following research methods were used: a review of literary sources; visometry; refractometry; pedagogical testing; methods of mathematical statistics. Research results. Our studies showed that after 22 days from the start of classes, schoolchildren who were engaged in a sanatorium rehabilitation program improved their visual acuity and refractometry but not significantly. Whereas, the students of the experimental group using the author's program, which included the developed set of special exercises for eyesight, gymnastic exercises, morning hygienic gymnastics, dosed therapeutic walking in the area with hanging landmarks, outdoor games and relay races with the ball, helped to improve the function of the visual analyzer and indicators physical fitness at the sanatorium stage of physical rehabilitation. Conclusions. The analysis of visual acuity and refractometry in school-aged children with myopia, who were engaged in the author's physical rehabilitation program, allows us to state an improvement in the function of the visual analyzer and some indicators of physical fitness.

Keywords: schoolchildren, myopia, visual analyzer, physical rehabilitation, sanatorium stage

\section{References}

1. Avetisov, E. (2005) Zritel'nyye funktsii i ikh korrektsiya u detey. Moskva: Meditsina, 278. (in Russ.)

2. Avetisov, E. (1986) Blizorukost'. Moskva: Meditsina, 233. (in Russ.).

3. Ananyeva T.G., TuharV.O.(2016)Zastosuvannyafizioterapevtychnykh metodivu likuvanni miopiyiu ditey [Application of physiotherapeutic methods in the treatment of myopia in children]. Fizychna reabilitatsiya ta rekreatsiyno-ozdorovchi tekhnolohiyi. no 3 23-26. (in Ukr.).

4. Butov R.S. (2016). Fizychna reabilitatsiya ditey shkihoho viku z vadamy zoru v umovakh spetsializovanykh navcharykh zakladiv [Physical rehabilitation of school-aged children with sight defects in conditions of specialized educational establishments]. Avtoref. kand. nauk $z$ fiz. vih. $i$ sportu. Kyiv. 23. (in Ukr.).

5. Dugina L. (2016) Vplyv zasobiv fizychnoyi reabilitatsiyina fizychnyy rozvytok ditey z vadamy zoru [Influи и ence of physical rehabilitation means on physical development of children with visual impairment]. Fizychna reabilitatsiya ta rekreatsiyno-ozdorovchi tekhnolohiyi. no 3. 6772. (in Ukr.). 


\section{СЛОБОЖАНСЬКИЙ НАУКОВО-СПОРТИВНИЙ ВІСНИК:}

\section{Матеріали XIX Міжнародної науково-практичної конференції «Фізична культура, спорт і здоров'я: стан, проблеми та перспективи»}

6. Tymchyk O. Fizychna reabilitatsiya ditey shkil'noho viku z miopiyeyu I-III stupenyu [Physical rehabilitation of school-age children with grade I-III myopia]. Sportyvna nauka ta zdorov'ya lyudyny. no 1 (2). 107-119. (in Ukr.).

7. Nataliya I., Yevgen K. (2010). Likuval'ne plavannya, yak zasib fizychnoyi reabilitatsiyi ditey molodshoho shkil'noho viku z vadamy zoru [Therapeutic swimming as a means of physical rehabilitation for primary school children with visual impairments]. Teoriya ta metodyka fizychnoho vykhovannya. no 3. 27-29. (in Ukr.).

8. Romman Haytham, J. (2015). Fizychna reabilitatsiya shkolyariv z funktsional'nymy porushennyamy zoru na postklinichnomu etapi [Physical therapy schoolchildrens with functional disorders of postklinichnomu on stage]. Avtoref. kand. nauk z fiz. vih. i sportu. Kyiv. 20. (in Ukr.).

9. Ruban, L. A. (2016). Metody korektsiyi miopiyi fizychnymy vpravamy [Methods of myopia correction by physical exercises]. Pedahohichni nauky. Fizychne vykhovannya ta sport. no 2. 193-197. (in Ukr.).

10. Aslan, U., Calik, B., Kitiş, A. (2012) Vliyaniye pola i urovnya zreniya na uroven' fizicheskoy aktivnosti detey i podrostkov s narusheniyem zreniya [The effect of gender and level of vision on the physical activity level of children and adolescents with visual impairment]. Res Dev Disabil. J. no 33(6). 1799-804. (in Eng.).

11. Taylor, D., Hoyt, K. (2007) Pediatric Ophthalmology. Moscow: BINOMIAL, 248. (in Russ.)

12. Cochereau A. (2011). Skrining na narusheniya zreniya v doshkol'noy shkole [Screening for visual disorders in pre-primary school]. Soins. Pediatr. Pueric. no 261 24-25.(in Eng.).

13. Walline J.J, Lindsley K., Vedilla S.S. (2012). Blizorukost'. Pobochnyye effekty dlya detey [Myopia. Treatments for Kids Come Up Short or Cause Side Effects] // Review of Ortometry. no149 (1): 316. (in Eng.).

\section{Відомості про авторів / Information about the Authors}

Онищук Вікторія Євгенівна - кандидат наук з фізичного виховання і спорту доцент кафедри медико-біологічних основ фрізичного виховання і фізичної реабілітації Вінницького державного педагогічного університету імені М. Коцюбинського;

Онищук Виктория Евгеньевна - кандидат наук по физическому воспитанию и спорту доцент кафедры медико-биологических основ физического воспитания и физической реабилитации Винницкого государственного педагогического университета имени М. Коцюбинского;

Victoria Onishchuk - PhD (Physikal Education and Srort), associate professor of the department of biomedical foundations of physical education and physical rehabilitation of Vinnitsa State Pedagogical University named after M. Kotsyubinsky; e-mail vitapilgun@yandex.ru:

ORCID: 0000-0002-9615-6653

Гаврилова Наталія Володимирівна - кандидат наук з фізичного виховання і спорту, доцент кафедри медико-біологічних основ фізичного виховання і фізичної реабілітації Вінницького державного педагогічного університету імені М. Коцюбинського;

Гаврилова Наталья Владимировна - кандидат наук по физическому воспитанию и спорту доцент кафедры медикобиологических основ физического воспитания и физической реабилитации Винницкого государственного педагогического университета имени М. Коцюбинского;

Natalia Gavrilova - Ph.D. in physical education and sports, associate professor of the department of biomedical foundations of physical education and physical rehabilitation of Vinnitsa State Pedagogical University named after M. Kotsyubinsky; e-mail gavrilova.natal83@gmail.com; ORCID: 0000-0001-6209-5875

Мацейко Ірина Іванівна - кандидат наук з фрізичного виховання і спорту, доцент кафедри медико-біологічних основ фрізичного виховання і фізичної реабілітації Вінницького державного педагогічного університету імені М. Коцюбинського;

Мацейко Ирина Ивановна - кандидат наук по фризческому воспитанию и спорту доцент кафедры медико-биологических основ физического воспитания и физической реабилитации Винницкого государственного педагогического университета имени М. Коцюбинского;

Irina Matseyko - Ph.D. in physical education and sports, associate professor of the department of biomedical foundations of physical education and physical rehabilitation of Vinnitsa State Pedagogical University named after M. Kotsyubinsky; e-mail iryna.isd1@gmail.ru; ORCID:0000-0002-2656-6200

Звіряка Олександр Миколайович - к. фріз. вих., доцент; Сумський державний педагогічний університет імені А.С. Макаренка, Навчально- науковий інститут фрізичної культури, Суми, Україна.

Звиряка Александр Николаевич - к. физ. восп., доцент; Сумской государственный педагогический университет имени

А.С. Макаренка, Научно-исследовательский институт физической культуры, г. Сумы, Украина.

Oleksandr Zviriaka - PhD (Physical Education and Sport), Associate Professor; Sumy State Pedagogical University named after A. S. Makarenko, Educational and Research Institute of Physical Culture, Sumy, Ukraine.

ORCID.ORG/0000-0001-8618-9665

e-mail: zvir-hunter@ukr.net 